\title{
Understanding Farmers' Perceptions and Adaptations to Precipitation and Temperature Variability: Evidence from Northern Iran
}

\author{
Mohammad Sadegh Allahyari ${ }^{1, *}$, Sahereh Ghavami ${ }^{1}$, Zahra Daghighi Masuleh ${ }^{2}$, \\ Anastasios Michailidis ${ }^{3}$ and Stefanos A. Nastis ${ }^{3}$ \\ 1 Department of Agricultural Management, Rasht Branch, Islamic Azad University, Rasht 4147654919, Iran; \\ allahyari@iaurasht.ac.ir \\ 2 Department of Agricultural Economics, Payame Noor University (PNU), Tehran, 19395-4697, Iran; \\ z.daghighi.m@shargh.tpnu.ac.ir \\ 3 Laboratory of Agricultural Extension \& Rural Sociology, Department of Agricultural Economics, \\ Faculty of Agriculture, School of Agriculture, Forestry and Environmental Sciences, Aristotle University of \\ Thessaloniki, 54124 Thessaloniki, Greece; tassosm@auth.gr (A.M.); snastis@auth.gr (S.A.N.) \\ * Correspondence: allahyari@iaurasht.ac.ir; Tel.: +98-911-383-7073
}

Academic Editor: Angelika Ploeger

Received: 19 February 2016; Accepted: 24 November 2016; Published: 3 December 2016

\begin{abstract}
Precipitation and temperature variability present significant agricultural risks worldwide. Northern Iran's agriculture mainly depends on paddy fields, which are directly affected by precipitation and temperature variability. The main aim of this study is to explore farmers' attitudes towards precipitation and temperature variability and their adaptation strategies in paddy fields in a typical agricultural province in northern Iran. Primary survey data were collected from a sample of 382 paddy farmers of Rasht County in Guilan Province. Data have been analyzed using both summary statistics and bivariate analysis (Pearson, Spearman, and Eta correlation coefficients). Empirical findings reveal that most paddy farmers had experienced precipitation and temperature variability and were taking measures to reduce its negative impacts on their crops. Results also indicate that farm size and household income influence farmers' perception to precipitation and temperature variability, while availability of water resources also influence farmers' adaptation decisions.
\end{abstract}

Keywords: adaptation strategies; precipitation and temperature variability; Iran; paddy fields

\section{Introduction}

Agriculture plays an important role in the global gross domestic product (GDP) and provides employment for 1.3 billion people (i.e., $22 \%$ of the world's population). In many developing countries, increasing agricultural production has been one of the most important priorities for agricultural development programs [1]. Agriculture is the most important economic sectors in Iran and is highly dependent on climate. The impact of global climatic change on agriculture, and especially precipitation and temperature variability (PTV), has recently become an issue of increasing importance. Drought, lower precipitation and higher temperatures are the most costly natural disasters in Iran. Iran has experienced 27 drought occurrences in the past 40 years [2,3]. While some aspects of climate change, such as increased precipitation, may bring localized benefits, there will also be a range of adverse impacts including reduced water availability, more frequent extreme weather events, and lower productivity of some crops, resulting in the reduction of farmers' income [4,5]. PTV will be followed by economic shocks on prices, supply, demand, trade, comparative advantages, and consumers' and producers' welfare [6]. Hence, farmers need to apprehend the impact of PTV and the scope of adaptation strategies in paddy fields. 
According to Udmale et al. [7], many of the environmental impacts, such as increases in average atmospheric temperature, were perceived by most farmers, and these perceptions are formed and reinforced through both everyday experiences and various outside sources. A better understanding of farmers' perceptions on PTV, their ongoing adaptation measures, and other related factors is important for informing policies that are aimed at promoting successful adaptations in the agricultural sector [8,9]. Farm practices are modified in response to various external triggers such as new market opportunities or failures, and also in response to PTV [10].

Adaptation is one policy option for alleviating the negative impacts of PTV at the farm level. Economic constraints and barriers to adaptation such as social acceptance, workload, biodiversity, and many others limit farmers' adaptation. These actions include strategies such as alterations in crop management (e.g., planting dates or crop varieties), land use, and land management (e.g., fallowing, irrigation and water harvesting, soil and water conservation measures, or tillage practices) and livelihood strategies (e.g., change in the mix of crops or livestock produced, combination of farm and nonfarm activities, or temporary or permanent migration) $[9,11,12]$. One important issue in agricultural adaptation to PTV is the manner in which farmers update their expectations of the future climate in response to unusual weather patterns [13]. Another important issue related to adaptation in agriculture is how perceptions of PTV are translated into agricultural decisions. If farmers learn gradually about the change in precipitation and temperature, they will also learn gradually about the best techniques and adaptation options available. Farmers learn about the best adaptation options in three ways: (1) learning by doing; (2) learning by copying; and (3) learning from instruction [14]. Adaptation to PTV refers to adjustment in natural or human systems in response to actual or expected climatic stimuli or their effects, which moderates harm or exploits beneficial opportunities [15].

Supplying more than $70 \%$ of human caloric intake in some countries and over $30 \%$ in Asia, rice (Oryzasativa) is one of the most important agricultural crops in the world. Iran together with India, Pakistan, Korea, China, Taiwan, and Thailand are some of the main rice-producing countries in Asia. In Iran, it is typically consumed at least once a day as part of the main meal and is the second main source of calories after wheat. The highest concentration of rice production in Iran is in the three northern provinces of Guilan, Mazandaran, and Golestan. Guilan province is the main rice-growing area in Iran and is one of the provinces that have attracted much attention regarding its agricultural products, especially rice [16,17]. Annually importing $1.7 \mathrm{Mt}$ rice, Iran is the second largest rice importer after the Philippines. Therefore, efforts are immediately required to increase rice production [18]. Rice cultivation in Guilan-due to its higher water requirements, compared to other cereals-has been severely affected by PTV in recent years.

Guilan province is highly exposed to natural disasters as well as the potential impact of PTV. Climatic factors such as PTV could affect the paddy fields and are a major challenge to agricultural development. Although Guilan farmers have a low capacity to adapt to such changes, they have survived and adapted in various ways over time. A better understanding of how they have coped and how they perceive PTVis essential in creating incentives to enhance farm-level adaptation. The goal of PTV perception and adaptation strategies is to enhance communities' resilience towards various changes in their natural environment. Resilience is the capacity to maintain competent functioning in the face of major life stressors. A better understanding of farmers' ongoing adaptation measures and their perception toward PTV could not only improve policies and management decisions, but also increase the farm households' ability to adapt [9-19].

Reliable statistics indicate that Guilan province will face severe water shortage and drought in the future, and these problems, more than anything, will affect rice production [20]. In recent years, a number of studies have been conducted to assess farmers' attitudes, perception, and adaptation strategies to PTV. However, due to different study areas, results vary. Table 1 summarizes some related studies conducted over the past 10 years and their main results proposed by researchers such as Abid et al. [21], Jianjun et al. [9], Yu et al. [22], Smithet al. [23], Rogé et al. [24], Arbuckle Jr. et al. [25], 
Amdu et al. [26], Nizam [27], Nastis et al. [28], Sofoluwe et al. [29], Smith and Olesen [12], Tologbonse et al. [30], Deressa et al. [14], and Hassan and Nhemachena [31].

Table 1. Overview of integrated studies.

\begin{tabular}{|c|c|c|c|}
\hline Author(s) & Year & Main Goal & Main Results \\
\hline Abid et al. & 2015 & $\begin{array}{l}\text { How farmers perceive climate change } \\
\text { and how they adapt their farming in } \\
\text { response to perceived changes in climate }\end{array}$ & $\begin{array}{l}\text { Awareness of climate change is widespread } \\
\text { throughout the area, and farm households make } \\
\text { adjustments to adapt their agriculture in } \\
\text { response to climate change }\end{array}$ \\
\hline Jianjun et al. & 2015 & $\begin{array}{l}\text { Examined the effects of farmers' risk } \\
\text { preferences on climate change adaptation } \\
\text { strategies in China }\end{array}$ & $\begin{array}{l}\text { The level of education, farming experience, } \\
\text { farm size, household income, and perception of } \\
\text { climate change impacts influence farmers' } \\
\text { adaptation decisions }\end{array}$ \\
\hline Yuet al. & 2014 & $\begin{array}{l}\text { How smallholder farmers perceive } \\
\text { climate change and adapt their } \\
\text { agricultural activities }\end{array}$ & $\begin{array}{l}\text { Increased annual average temperature and } \\
\text { decreased annual precipitation were correctly } \\
\text { perceived by farmers, these perceptions enabled } \\
\text { local farmers to make appropriate adaptations } \\
\text { to cope with climate change }\end{array}$ \\
\hline Smith et al. & 2014 & $\begin{array}{l}\text { Perform comparative research regarding } \\
\text { the climate change assumptions, risk } \\
\text { perceptions, policy preferences, } \\
\text { observations, and knowledge among } \\
\text { rural Nevada's tribes and tribal } \\
\text { environmental leaders, non-native } \\
\text { ranchers and farmers, and America's } \\
\text { general public }\end{array}$ & $\begin{array}{l}\text { The majority of respondents believe that human } \\
\text { activity is playing a significant role in climate } \\
\text { change and is inevitable }\end{array}$ \\
\hline Rogé et al. & 2014 & $\begin{array}{l}\text { Describing an interdisciplinary } \\
\text { methodology for helping small farmers } \\
\text { prepare for climatic variability }\end{array}$ & $\begin{array}{l}\text { Highlighted the depth of farmers' knowledge } \\
\text { for dealing with climate change and were more } \\
\text { interested in stabilizing fluctuations in yields } \\
\text { over time rather than maximizing yield } \\
\text { potential }\end{array}$ \\
\hline Arbuckle Jr. et al. & 2013 & $\begin{array}{l}\text { Examining the adaptation and mitigation } \\
\text { actions, and how beliefs and concerns } \\
\text { about climate change } \\
\text { influence those actions }\end{array}$ & $\begin{array}{l}\text { Farmers who were concerned about the impacts } \\
\text { of climate change on agriculture and attributed } \\
\text { it to human activities had more positive } \\
\text { attitudes toward both adaptive and mitigation } \\
\text { management strategies }\end{array}$ \\
\hline Amdu et al. & 2013 & $\begin{array}{l}\text { Examining the perception of farmers } \\
\text { towards climate change, assessed local } \\
\text { impacts of climate change on the } \\
\text { agricultural sector, identified local } \\
\text { innovations for climate change } \\
\text { adaptation, and assessed the barriers and } \\
\text { determinants of climate change } \\
\text { adaptation options at the farm level }\end{array}$ & $\begin{array}{l}\text { The perception of most farmers on temperature } \\
\text { rise was in harmony with the trend analysis of } \\
\text { temperature records, but there was a clear } \\
\text { contradiction between the perception of the } \\
\text { majority of farmers on precipitation volume and } \\
\text { the trend analysis of the precipitation records }\end{array}$ \\
\hline Nizam & 2013 & $\begin{array}{l}\text { Identifying temporal precipitation and } \\
\text { temperature variability in Anuradhapura } \\
\text { district from } 1941 \text { to } 2010 \text { and determine } \\
\text { farmers' perception to climate change }\end{array}$ & $\begin{array}{l}\text { Farmers have already identified that climate is } \\
\text { changing and they knew how to face these } \\
\text { changes but they need more awareness about } \\
\text { how to adapt to climate change }\end{array}$ \\
\hline Nastis et al. & 2012 & $\begin{array}{l}\text { Analyzing the economic costs of climate } \\
\text { change in Greek agricultural } \\
\text { productivity during the last } 30 \text { years and } \\
\text { adaptation strategies }\end{array}$ & $\begin{array}{l}\text { The adaptation to climate change involves both } \\
\text { the restructuring of crops as well as changes in } \\
\text { cultivation practices }\end{array}$ \\
\hline Sofoluwe et al. & 2011 & $\begin{array}{l}\text { Investigating the perception of farmers } \\
\text { to climatic variable changes, adaptation } \\
\text { methods adopted, and factors } \\
\text { influencing the choice of adaptation } \\
\text { methods }\end{array}$ & $\begin{array}{l}\text { Most of the farmers were aware of the increase } \\
\text { in temperature and decline in precipitation. } \\
\text { Majority of them perceived a decline in the level } \\
\text { of precipitation }\end{array}$ \\
\hline Smith \& Olesen & 2010 & $\begin{array}{l}\text { Adaptation to climate change } \\
\text { in agriculture }\end{array}$ & $\begin{array}{l}\text { More options for adaptation to climate change } \\
\text { have a positive impact on mitigation strategy }\end{array}$ \\
\hline Tologbonse et al. & 2010 & $\begin{array}{l}\text { Determine the farmers' perception of the } \\
\text { effects of climate change and coping } \\
\text { strategies in three agro-ecological zones } \\
\text { of Nigeria }\end{array}$ & $\begin{array}{l}\text { Farmers are fully aware of the effect of climate } \\
\text { change, and planting of drought-resistant crops } \\
\text { or varieties was the selected strategy }\end{array}$ \\
\hline Deressa et al. & 2009 & $\begin{array}{l}\text { Identifying the major methods used by } \\
\text { farmers to adapt to climate change in the } \\
\text { Nile Basin of Ethiopia, the factors that } \\
\text { affect their choice of method, and the } \\
\text { barriers to adaptation }\end{array}$ & $\begin{array}{l}\text { The methods identified include use of different } \\
\text { crop varieties, tree planting, soil conservation, } \\
\text { early and late planting, and irrigation. The main } \\
\text { barriers include lack of information on } \\
\text { adaptation methods and financial constraints }\end{array}$ \\
\hline $\begin{array}{l}\text { Hassan \& } \\
\text { Nhemachena }\end{array}$ & 2008 & $\begin{array}{l}\text { Analyzing determinants of farm-level } \\
\text { climate adaptation measures in Africa }\end{array}$ & $\begin{array}{l}\text { Specialized crop cultivation (mono-cropping) is } \\
\text { the agricultural practice most vulnerable to } \\
\text { climate change in Africa }\end{array}$ \\
\hline
\end{tabular}


The main aim of this study was to identify the paddy farmers' understanding of precipitation and temperature changes, how it impacts their farming, and their coping and adaptation strategies in Rasht County of Guilan province. In particular, this study was designed to meet the following objectives: (1) to describe the sociodemographic characteristics of paddy farmers; (2) to characterize their perception of precipitation and temperature changes; (3) to identify adaptation measures for precipitation and temperature changes; and (4) to determine the relationship between farmers' perception of precipitation and temperature changes and their sociodemographic characteristics. The next section provides a background of the case study area followed by a brief presentation of applied methodology, while data collection information is also outlined. Afterwards, summary statistics and a brief discussion of the findings are presented, ensued by the results of the bivariate analysis. Finally, the paper concludes. Below, Figure 1 briefly presents the general methodological framework of data collection, statistical analysis, and obtained results.

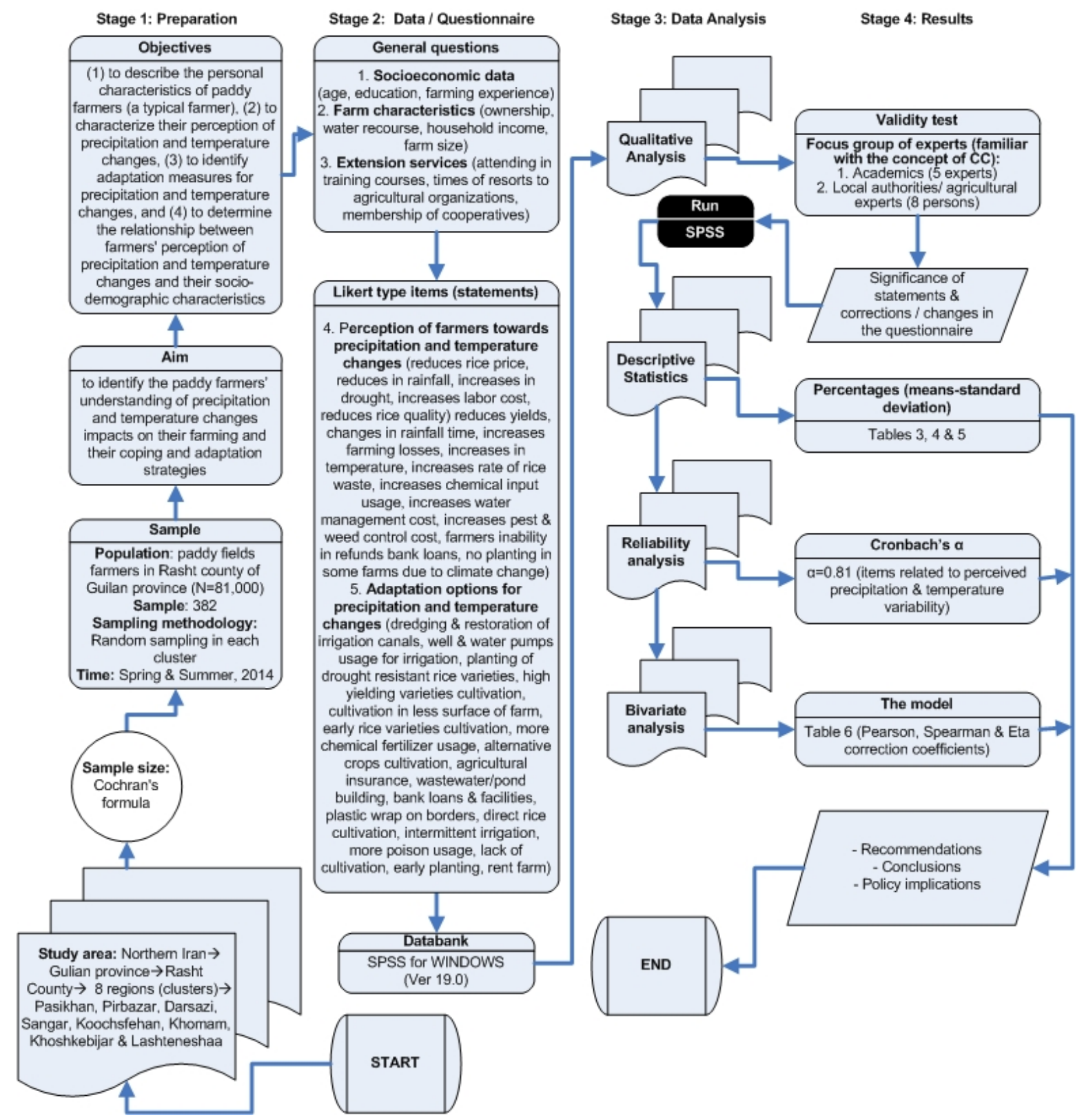

Figure 1. Methodological framework. 


\section{Employed Methodology}

\subsection{Study Area}

The study area was Rasht County in Guilan province. This province was selected for its high percentage of rice cultivation. The province of Guilan, in the northern part of Iran, covers an area of $14,711 \mathrm{~km}^{2}$ and has a population of 2,403,716. It has approximately 400,000 ha of agricultural land, $60 \%$ of which is allocated to rice cultivation. Guilan province has 230,000 ha of paddy fields with an annual production of 700,000 tons of white rice. This amounts to 30\% of Iran's rice production. Guilan province is characterized by a temperate climate, adequate water supplies, and fertile soil with good texture and structure, making it a highly suitable area for rice cultivation. The capital of Guilan is Rasht County (Figure 2).

Rasht County is characterized by an average annual precipitation of $1500 \mathrm{~mm}$ and monthly average temperatures of $15.8^{\circ} \mathrm{C}$ as well as $81 \%$ annual relative moisture. Because of its vast available lands and soil fertility, this county has been reputed to be one of the most suitable areas for rice cultivation during the past decades [32].

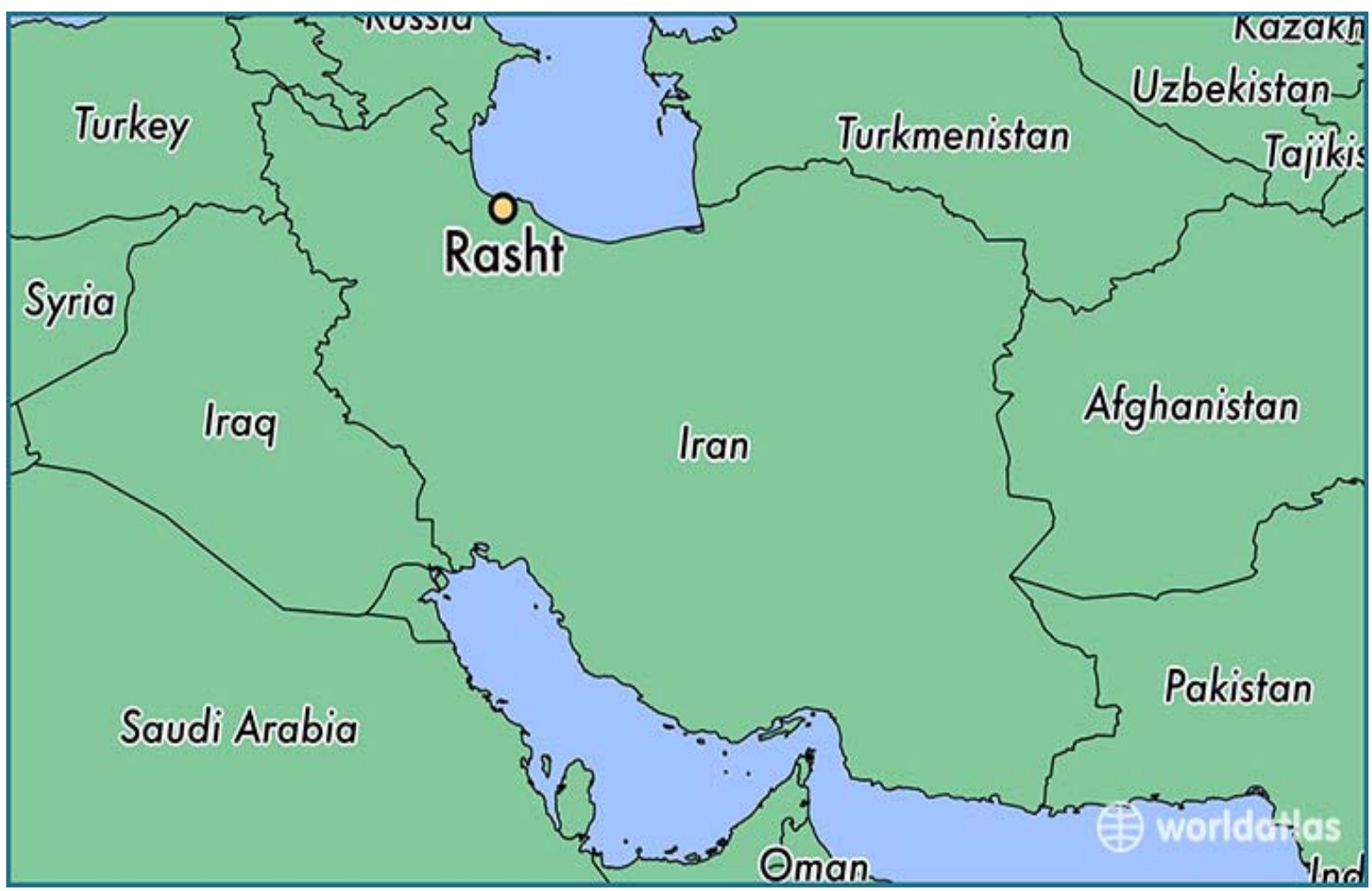

Figure 2. Location of Rasht County.

Monthly average precipitation, temperature, and daytime in Rasht County are shown in Table 2, while the annual mean precipitation and the annual mean temperature in Rasht County for2007-2014are shown in Figures 3 and 4, respectively. According to the World Meteorological Organization [33], during 2007-2014, the study area received annual precipitation ranging from $1824.8 \mathrm{~mm}$ in 2011 to $1178.6 \mathrm{~mm}$ in 2014 , and annual temperature ranging from $14.2{ }^{\circ} \mathrm{C}$ in 2007 and 2008 to $15.4^{\circ} \mathrm{C}$ in 2014 . 


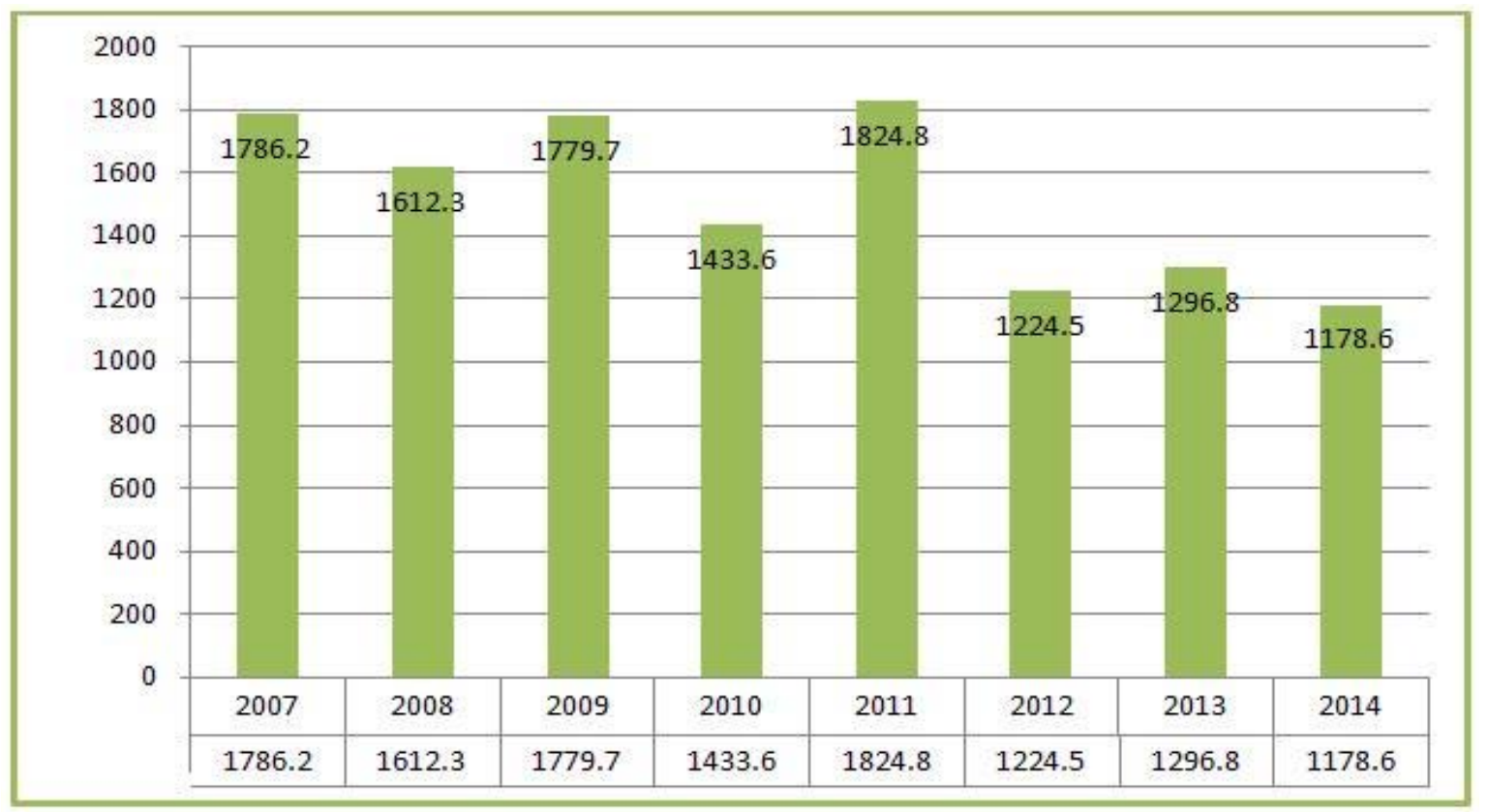

Figure 3. Annual precipitation (mm) in Rasht County.

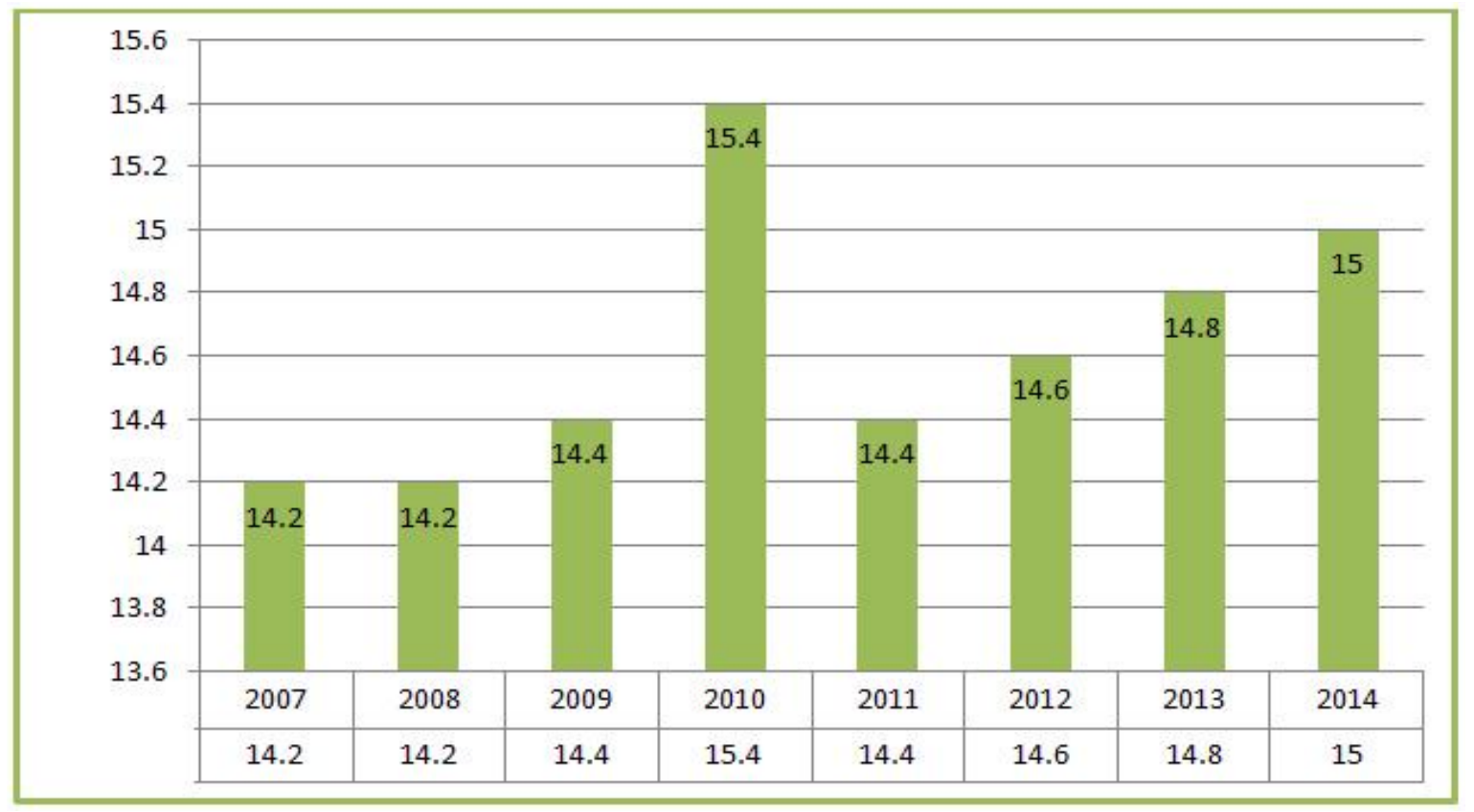

Figure 4. Annual temperature $\left({ }^{\circ} \mathrm{C}\right)$ in Rasht County.

Table 2. Monthly weather average (2014).

\begin{tabular}{cccccccccccccc}
\hline Average Values & Annual & January & February & March April & May & June & July & August & September & October & November & December \\
\hline Temperature $\left({ }^{\circ} \mathrm{C}\right.$ ) & 15 & 5.5 & 5.5 & 8.9 & 12.8 & 18.9 & 21.7 & 23.9 & 23.9 & 20.6 & 16.7 & 12.8 & 7.8 \\
Precipitation $(\mathrm{mm})$ & $1178.6^{*}$ & 91.5 & 91.5 & 104.1 & 55.9 & 38.1 & 25.4 & 17.9 & 58.4 & 193 & 228.6 & 170.2 & 109.2 \\
Daytime $(\mathrm{h})$ & 12.6 & 10.4 & 11.3 & 12.4 & 13.6 & 14.7 & 15.2 & 14.9 & 14 & 12.8 & 11.7 & 10.6 & 10.1 \\
\hline \multicolumn{18}{c}{ * Total precipitation in 2014, Source: [34]. }
\end{tabular}

Evidence that climate is changing-particularly that precipitation is reducing-in the study area is that precipitation input to Sefid-Roud dam in the autumn season has reduced in recent years. In the past 50 years, the highest amount was 1531 (million $\mathrm{m}^{3}$ ) in 1995. In 2011 this amount reduced significantly 
to 116 (million $\mathrm{m}^{3}$ ) and in the past years' autumn (2015), precipitation input to Sefid-Rouddam was 165 (million $\mathrm{m}^{3}$ ) (Guilan Regional Water Authority). Sefid-Roud basin, which drains an area of approximately 56,700 square kilometers, is known as one of the most important basins that provide water for nine provinces of Iran and is the primary water source for many provinces, especially for Guilan province [35]. Thus, this reduction can have harmful effects on regional cultivation and creates an essential need to manage PTV impacts.

\subsection{Data Collection}

The research design of the study was a descriptive survey. The target population of this study was the paddy fields farmers in Rasht county of Guilan province $(N=81,000)$. First, Cochran's formula [36] was employed to determine the sample size, and then 382 farmers were selected (during spring and summer, 2014) to answer a questionnaire using the typical cluster sampling method. There were eight regions in Rasht County (namely Pasikhan, Pirbazar, Darsazi, Sangar, Koochsfehan, Khomam, Khoshkebijar, and Lashtenesha). Each region was considered as a cluster, and the population was divided into eight groups or clusters. Sampling in each cluster was done using random sampling. The instrument used in this study was a questionnaire (Appendix A) whose validity was confirmed by a panel of experts from university faculty members and agricultural experts of Guilan province, familiar with climate change [37]. Based on the proposed methodology [37], each expert gave his/her point of view about the validity of each statement and proposed some corrections or recasting of a few statements. On the basis of their views, some statements were deleted, some others were rephrased, and very few new ones were proposed.

The representativeness of the sample has been tested using mainly descriptive statistics. In particular, whether a number of statistics that are descriptive of a distribution are the same in the research sample and the population has been checked [38]. More specifically, tests have been conducted for: (a) mean difference; (b) median difference; (c) stochastic dominance; (d) variance difference; and (e) shape of the 13sociodemographic characteristics in the first part of the questionnaire (these data are available from the statistical service of Iran and other sources for the whole population of the study area). According to this procedure, the selected sample $(n=382)$ is almost ideal and representative, as in all the conducted tests there were no statistically significant differences between the research sample and the population.

From a technical-architectural point of view, the design process of the questionnaire is divided into three levels of functionality (Figure 1). These three levels consist of: (a) a section that provides information about sociodemographic characteristics of the respondents; (b) a section that investigates farmers' perception of precipitation and temperature changes on their farming (15 statements); and finally (c) a section that investigates farmers' adaptation measures for particular PTV (18 practices). Each one of these items (sections $b$ and c) were scaled by a 5-level Likert-type scale, where strongly agree $=5$ and strongly disagree $=1$.

The main reason for this design is that when responding to a Likert questionnaire item, respondents specify their level of agreement or disagreement on a symmetric agree-disagree scale, assuming equal distances between each item and between each sequential possible answer [39]. Using reliability analysis for all the items, we can determine the extent to which these items are related to each other, to get an overall index of the internal consistency of the scale as a whole, and to identify items that had to be excluded from the scale. Having accepted the consistency of the items, the average rankings for each respondent were used as numerical values in multivariate analysis.

The questionnaire was administered through face-to-face interviews with the paddy farmers. Although expensive, face-to-face interviews provide the highest response rates and are better suited to collecting complex information. The interviews were conducted in a friendly manner and there was good cooperation with the respondents without any refusals. This approach enabled the interviewer to explain clearly the details of the questionnaire. The primary data were processed and statistically 
analyzed using the SPSS 19 Statistical Software Package. Descriptive and inferential statistics were employed to assess farmers' perceptions and adaptation measures toward the impacts of PTV.

\section{Results and Discussion}

\subsection{Population Profile}

Distribution of respondents' sociodemographic characteristics are shown in Table 3. As the results indicate, only $6.3 \%$ of farmers were younger than 40 years old, 39\% of them were within the age range of 51-60, and respondents' average age was 55.9 years old. All of them were male and married. Respondents with elementary education had the highest prevalence in the sample (51\%). Farmers with farming experience of more than 46 years had the highest frequency (38\%) and those with 5-15 years had the lowest (1\%). The mean experience of farmers was 42.3 years. About $89 \%$ of farmers had exclusively private land and $1 \%$ of them had leased land. Most of them (48\%) used irrigation canals as their water resource. With regard to farm size, $57.8 \%$ of farmers had $<1$ ha and $42.2 \%$ had $>1$ ha and the farms' average size was 0.8 ha. Also, the majority of them (56\%) reported average income $(\$ 3,786-\$ 5,679)$. With regard to membership in cooperatives, $75.2 \%$ of farmers weren't members and $88 \%$ of farmers had not attended training courses during the past two years.

Table 3. Frequency distribution of farmers' sociodemographic characteristics.

\begin{tabular}{|c|c|c|c|c|}
\hline Characteristics & Frequency & Percent/Valid & Mean & SD \\
\hline Age (years) & & & 55.9 & 9.9 \\
\hline Less than 40 & 24 & 6.3 & & \\
\hline $41-50$ & 91 & 23.9 & & \\
\hline $51-60$ & 149 & 39.0 & & \\
\hline More than 60 & 118 & 30.1 & & \\
\hline Farming Experience (years) & & & 42.3 & 11.8 \\
\hline $5-15$ & 4 & 1.0 & & \\
\hline $16-25$ & 46 & 12.0 & & \\
\hline $26-35$ & 57 & 15.0 & & \\
\hline $36-46$ & 130 & 34.0 & & \\
\hline More than 46 & 145 & 38.0 & & \\
\hline \multicolumn{5}{|l|}{ Level of Education } \\
\hline Illiterate & 46 & 12.0 & & \\
\hline Elementary & 195 & 51.0 & & \\
\hline Secondary & 134 & 35.1 & & \\
\hline Collegiate & 7 & 1.8 & & \\
\hline \multicolumn{5}{|l|}{ Farm size } \\
\hline Less than 1 ha & 221 & 57.8 & & \\
\hline More than 1 ha & 161 & 42.2 & & \\
\hline \multicolumn{5}{|l|}{ Farm ownership } \\
\hline Private land & 340 & 89.0 & & \\
\hline Leased land & 4 & 1.0 & & \\
\hline Sharecropping 50:50 & 8 & 2.1 & & \\
\hline Private and leased land & 30 & 7.9 & & \\
\hline \multicolumn{5}{|l|}{ Water resource } \\
\hline Well & 8 & 2.1 & & \\
\hline Irrigation canal & 183 & 48.0 & & \\
\hline River & 160 & 41.9 & & \\
\hline Well and River & 31 & 8.1 & & \\
\hline
\end{tabular}


Table 3. Cont.

\begin{tabular}{|c|c|c|c|c|}
\hline Characteristics & Frequency & Percent/Valid & Mean & SD \\
\hline \multicolumn{5}{|c|}{ Attended training courses } \\
\hline Yes & 46 & 12.0 & & \\
\hline No & 336 & 88.0 & & \\
\hline \multicolumn{5}{|c|}{$\begin{array}{l}\text { Times requested } \\
\text { information from } \\
\text { agricultural organization }\end{array}$} \\
\hline None & 222 & 58.1 & & \\
\hline $1-3$ times & 126 & 33.0 & & \\
\hline More than 3 times & 34 & 8.9 & & \\
\hline \multicolumn{5}{|l|}{$\begin{array}{l}\text { Membership in } \\
\text { cooperatives }\end{array}$} \\
\hline Yes & 95 & 24.9 & & \\
\hline No & 287 & 75.1 & & \\
\hline \multicolumn{5}{|c|}{ Annual household income } \\
\hline Less than $\$ 3,786$ & 126 & 33.0 & & \\
\hline$\$ 3,786-\$ 5,679$ & 214 & 56.0 & & \\
\hline More than $\$ 5,679$ & 42 & 11.0 & & \\
\hline
\end{tabular}

\subsection{Perception towards Precipitationand Temperature Variability}

Perception towards PTV was assessed by 15 statements and the level of farmers' agreement was identified and scaled. Given that all questions have been measured according to a 5-point Likert scale, 2.5 was considered as the cut-off point. That is to say that if the mean value of a statement is greater than 2.5, respondents have a positive attitude toward this statement (they agree) while if the mean value of a statement is less than 2.5, respondents have a negative attitude toward this statement (they disagree). Mean scores close to 5 indicate strong agreement while, on the other hand, mean scores close to 1 indicate strong disagreement. In Table 4, the mean score and standard deviation for each statement are shown. Farmers strongly agree with 12 statements (out of 15), suggesting that farmers are aware that precipitation and temperature changes have indeed increased temperature, labor and management costs, drought, and rate of sickness, and have reduced rice quality, precipitation, and productivity.

Table 4. Paddy farmers' perception towards precipitation and temperature variability (PTV).

\begin{tabular}{clcc}
\hline & \multicolumn{1}{c}{ Statements } & Mean & SD \\
\hline 1 & PTV increases farming losses. & 4.31 & 0.465 \\
2 & Precipitation timing has been changed in recent years. & 4.29 & 0.456 \\
3 & PTV increases labor cost in rice fields. & 4.26 & 0.441 \\
4 & Precipitation has been decreased in recent years. & 4.23 & 0.423 \\
5 & Temperature has been increased in recent years. & 4.22 & 0.418 \\
6 & Drought has occurred more frequently in recent years. & 4.22 & 0.462 \\
7 & PTV have reduced rice quality. & 4.17 & 0.428 \\
8 & PTV have increased the costs of pest and weed control. & 4.17 & 0.378 \\
9 & PTV have increased the rate of rice waste. & 4.15 & 0.359 \\
10 & PTV have reduced rice yield. & 4.15 & 0.386 \\
11 & PTV have increased the costs of water management. & 4.14 & 0.349 \\
12 & PTV have reduced rice price due to the loss of the quality. & 4.06 & 0.565 \\
13 & Temperature rise have resulted in farmers' inability to repay bank loans. & 2.45 & 0.627 \\
14 & PTV have increased the application rate of chemical inputs. & 2.41 & 0.534 \\
15 & PTV have resulted in the desolation of some farms. & 2.11 & 0.567 \\
\hline
\end{tabular}




\subsection{Adaptation Measures towards PTV}

To find the better measures towards PTV adaptation in Rasht County, respondents were asked to show to what extent each adaptation measure is useful and practical in their area. Mean scores revealed that early-maturing rice varieties, irrigation canals, drought-resistant rice varieties, early planting, agricultural insurance, plastic wrap, and pesticide usage are the major adaptation measures used by paddy farmers for counteracting the changing climate in Rasht county (Table 5). Agreement level with the other statements was below the cut-off point.

Table 5. Ranking of adaptation measures toward PTV.

\begin{tabular}{clcc}
\hline & \multicolumn{1}{c}{ Adaptation Measures } & Mean & SD \\
\hline 1 & Cultivation of early-maturing rice varieties & 4.48 & 0.502 \\
2 & Dredging and restoration of irrigation canals & 4.33 & 0.473 \\
3 & Planting of drought resistant rice varieties & 4.15 & 0.642 \\
4 & Early planting & 4.08 & 0.394 \\
5 & Agricultural insurance & 4.04 & 0.751 \\
6 & Plastic wrap on borders & 3.48 & 1.010 \\
7 & Increase pesticide usage & 2.69 & 0.615 \\
8 & Intermittent irrigation & 2.47 & 0.771 \\
9 & Increase chemical fertilizer usage & 1.53 & 0.674 \\
10 & Cultivation of high yielding varieties & 1.41 & 0.714 \\
11 & Usage of wells and water pumps for irrigation & 1.33 & 0.587 \\
12 & Alternative crops cultivation & 1.27 & 0.510 \\
13 & Bank loans and facilities & 1.23 & 0.649 \\
14 & Cultivate in less farm area & 1.19 & 0.581 \\
15 & Stop cultivation & 1.11 & 0.424 \\
16 & Wastewater (pond) building & 1.04 & 0.243 \\
17 & Rent farm & 1.03 & 0.171 \\
18 & Direct rice cultivation & 1.00 & 0.000 \\
\hline
\end{tabular}

\subsection{Bivariate Analysis}

Onwards, reliability analysis for 15 independent variables (Table 4) was used in order to determine the extent to which these variables are related to each other, to get an overall index of the internal consistency of the scale as a whole, and to identify items that had to be excluded from the scale. In fact, none of the independent variables were excluded. The value of Cronbach's alpha $(\alpha)$ reliability coefficient was found equal to 0.81 , thus indicating that the "farmers' perception" scale is reliable. Friedman's two-way analysis of variance, with $x^{2}=2.328(\alpha=0.00)$, and Hotelling's $T^{2}=1.112$ $(\mathrm{F}=28.16$ and $\alpha=0.00)$, indicated the significance in differences of item means. Having accepted the consistency of the 15 items, the average rankings for each respondent were used as the numerical values of the dependent variable "farmers' perception" which, along with the categories of thirteen other independent variables, are shown in Table 6.

Afterwards, Pearson, Spearman, and Eta correlation coefficients were estimated to assess the relation between farmers' sociodemographic characteristics (personal and production unit characteristics) and their perceptions. Pearson for measurable or continuous variables, Spearman for ordinal variables (or when one of the variables is quantitative), and Eta for nominal variables. Results in Table 6 indicate the relationship between farmers' sociodemographic characteristics and their perceptions towards PTV. Results indicate a positive relationship between farm size, household income, and farmers' perceptions. We can state that $4.84 \%\left(0.22^{2}\right)$ of the variation in "farmers' perception" is explained by "household income" and $4.00 \%\left(0.20^{2}\right)$ is explained by "farm size". 
Table 6. Bivariate analysis (Pearson, Spearman, and Eta correlation coefficients).

\begin{tabular}{|c|c|c|c|c|}
\hline Variable 1 & Variable 2 & $\begin{array}{l}\text { Correlation } \\
\text { Coefficient }\end{array}$ & Coefficients & $p$-Value \\
\hline Household income & farmers' perception & Pearson & $0.22 *$ & 0.02 \\
\hline Farm size & farmers' perception & Pearson & 0.20 * & 0.04 \\
\hline Age & farmers' perception & Pearson & -0.08 & 0.42 \\
\hline Farming experience & farmers' perception & Pearson & 0.07 & 0.50 \\
\hline Level of education & farmers' perception & Spearman & 0.075 & 0.46 \\
\hline Farm ownership & farmers' perception & Eta & 0.17 & 0.09 \\
\hline Water resource & farmers' perception & Eta & 0.17 & 0.08 \\
\hline Gender & farmers' perception & Eta & 0.11 & 0.09 \\
\hline Marital status & farmers' perception & Eta & 0.12 & 0.08 \\
\hline Number of family members & farmers' perception & Pearson & -0.05 & 0.36 \\
\hline Membership in rural cooperatives & farmers' perception & Eta & 0.16 & 0.06 \\
\hline $\begin{array}{l}\text { Times requested information from } \\
\text { agricultural organization }\end{array}$ & farmers' perception & Pearson & -0.08 & 0.44 \\
\hline Attending extension training courses & farmers' perception & Eta & 0.13 & 0.07 \\
\hline
\end{tabular}

* indicates statistical direct relation at the $5 \%$ level.

\section{Conclusions}

A very important outcome of this study is that questionnaire results regarding PTV are in complete agreement with the actual empirical data indicating that farmers' perceptions are valid (Table 2 and Figures 3 and 4). This is very important for developing successful adaptation strategies. Being dependent on natural resources, rice production in Rasht County is particularly vulnerable to PTV. Hence, perception of adaptation measures to PTV is a very important issue. Adaptation to PTV has been an important research topic, especially in agriculture, ever since PTV has been commonly recognized [40]. The present study is a preliminary effort to assess paddy farmers' perception of PTV and adaptation strategies in Rasht County, Guilan province, Iran. In this study, first the literature on related subjects was examined and classified, and then the primary framework based on 15 statements for farmers' perception of PTV and 18 statements for their adaptation strategies were proposed.

Among the key findings of the research analysis are the following: (1) Paddy farmers of Rasht County are aware of the increase in temperature and the decline in precipitation. This result is contrary to the research results reported by Tologbonse et al. [30], Sofoluwe et al. [29] and Amdu et al. [26]. On the other hand, Ogalleh et al. [41], Oluwatusin [42], Shameem et al. [43], Devkota [44], and Falaki et al. [45] revealed that farmers appear to be well aware of PTV, which is quite similar to our findings; (2) A diversity of adaptation strategies was employed by the Rasht County paddy farmers to counteract the impacts of PTV. Farmers are fully aware of possible adaptation options and strongly agree with planting of early-maturing, drought- and flood-tolerant varieties, reduction of water loss through irrigation canals, and agricultural insurance. The assessed adaptation strategies by Abid et al. [21], Fosu-Mensah et al. [46], Paudel et al. [47], and Oluwatusin [35] can be compared to the most important adaptation strategies assessed in the current paper; (3) assessment of adaptation options of Rasht County paddy farmers explicitly indicated that the farming community had tried to counteract the impact of PTV by employing local adaptation strategies; (4) a positive relationship was found between farm size and farmers' perception of PTV; (5) a positive relationship was found between household income and farmers' perception of PTV. 
Farmers with larger farms can use multiple cropping and can integrate a livestock component, especially under dry-land conditions, to increase their income. Large farm sizes allow farmers to spread the risks of loss associated with changes in precipitation and temperature. The possibility of a reduction in water resources is a major threat in the paddy fields due to alterations in hydrologic cycles and changes in water availability, so most adaptation strategies in Rasht paddy fields are related to water and irrigation management. Some strategies here are suggested according to farmers' awareness of the impacts of PTV and appropriate adaptation strategies are proposed in order to increase rice quality and quantity in paddy fields.

According to farmers' tendency to grow varieties resistant to environmental conditions, it is recommended that research institutes study and report these varieties to farmers and farmers cultivate these crops with more confidence.

Regarding adaptation to PTV, it was found that paddy farmers who had farmed in years with more variable weather conditions had a higher tendency to use agricultural insurance, so it is suggested that the government implement comprehensive insurance of agricultural products to protect farmers against changing weather conditions.

Consequently, this study may provide interesting and initial observations and, in addition, it demonstrates verifiability. However, as a first systematic attempt to explore farmers' attitudes towards PTV and their adaptation strategies in paddy fields, our study was limited to a rather small region and a rather restrained amount of time for the observations. Therefore, any attempt to generalize our results should be done very carefully. Nevertheless, the observations made in this study provide a starting point for further research, which could extend the investigation to a more representative sample. For example, an interesting subject for further research is to extend the questionnaire and the analysis outside the study area to include more general climate change impacts.

Conclusively, taking into account the great importance of PTV as a principal change driver in agricultural areas, as well as the great contribution of the agricultural sector in the gross domestic product of the country, a study understanding farmers' perceptions and adaptation can prove extremely valuable. However, the results presented here are also great sources of information for policy makers and extension workers internationally. In particular, an extra purpose of this research is to assist policy makers, program planners, and extension and community workers to understand, implement, and promote developmental strategies in their respective countries. So, lessons learned here could well have resonance in many other countries well beyond the Rasht County in Guilan Province.

Acknowledgments: The authors are grateful to the paddy farmers in Rasht County who participated in the survey. The product of this research paper would not be possible without all of them. Financial support by Rasht Branch, Islamic Azad University Grant No. 4.5830 is acknowledged. In addition, the authors wish to thank the editor and three reviewers for valuable comments and suggestions that have improved the quality of the paper. All errors remain ours.

Author Contributions: Mohammad Sadegh Allahyari designed and managed the research content and methodology, and wringing of results and conclusions, Sahereh Ghavami collected and analyzed the data. Zahra Daghighi Masouleh wrote the paper, interpreted results and made corrections. Anastasios Michailidis contributed in the statistical analysis and to the response to the reviewer comments. However, this work has been organized and has been written in an absolutely collaborative way and Stefanos A. Nastis involved the collection of secondary data, the authoring of results and conclusions and the editing for English of the manuscript.

Conflicts of Interest: The authors declare no conflict of interest.

\section{Appendix A. Questionnaire}

\section{Appendix A.1. Part 1: Socio-Demographic Characteristics}

a1. Age: years

a2. Gender: Female Male

a3. Marital status: Single Married

a4. Level of education: Illiterate Elementary Secondary Collegiate 
a5. Number of family members:

a6. Farming experience: years

a7. Annual household income: Rials

a8. Membership in rural cooperatives: Yes No

a9. Times requested information from agricultural organization: times

a10. Attending extension training courses: Yes No

a11. Water resource: Well Irrigation canal River Well and river

a12. Farm size: ha

a13. Farm ownership: Private land Leased land Sharecropping 50:50 Private and leased land

\section{Appendix A.2. Part 2: Perception of Farmerstowards Precipitation and Temperature Changes}

The following set of questions asks your perception of farmers towards precipitation and temperature changes. Please indicate your answer by circling the most appropriate response. Any change (increase or decrease) should be considered during the last 4 years.

\begin{tabular}{|c|c|c|c|c|c|c|}
\hline \multicolumn{2}{|r|}{ Items/Statements } & \multirow{2}{*}{$\begin{array}{l}\text { Strongly } \\
\text { Agree }\end{array}$} & \multirow[t]{2}{*}{ Agree } & \multirow{2}{*}{$\begin{array}{l}\text { Neither } \\
\text { Agree/Nor } \\
\text { Disagree }\end{array}$} & \multirow[t]{2}{*}{ Disagree } & \multirow{2}{*}{$\begin{array}{l}\text { Strongly } \\
\text { Disagree }\end{array}$} \\
\hline b1 & $\begin{array}{l}\text { Temperature and precipitation changes have already } \\
\text { caused increase in farming losses }\end{array}$ & & & & & \\
\hline b2 & Precipitation time has changed in recent years & & & & & \\
\hline b3 & $\begin{array}{l}\text { Temperature and precipitation changes have already } \\
\text { caused increase in labor cost }\end{array}$ & & & & & \\
\hline b5 & Temperature has increased in recent years & & & & & \\
\hline b6 & Drought has increased in recent years & & & & & \\
\hline b7 & $\begin{array}{l}\text { Temperature and precipitation changes have already } \\
\text { caused reduction in rice quality }\end{array}$ & & & & & \\
\hline b10 & $\begin{array}{l}\text { Temperature and precipitation changes have already } \\
\text { caused reduction in rice yield }\end{array}$ & & & & & \\
\hline b11 & $\begin{array}{l}\text { Temperature and precipitation changes have already } \\
\text { caused increase in water management costs }\end{array}$ & & & & & \\
\hline b12 & $\begin{array}{l}\text { Temperature and precipitation changes have already } \\
\text { caused reduction in rice price }\end{array}$ & & & & & \\
\hline b13 & $\begin{array}{l}\text { Temperature and precipitation changes have already } \\
\text { caused farmers inability to refund bank loans }\end{array}$ & & & & & \\
\hline b14 & $\begin{array}{l}\text { Temperature and precipitation changes have already } \\
\text { caused increase in usage of chemical inputs }\end{array}$ & & & & & \\
\hline
\end{tabular}

Appendix A.3. Part 3: Adaptation Options for Precipitation and Temperature Changes

The following set of questions asks about adaptation measures toward precipitation and temperature changes. Please indicate your answer by circling the most appropriate response. Any change (increase or decrease) should be considered during the last 4 years. 


\begin{tabular}{|c|c|c|c|c|c|c|}
\hline \multicolumn{2}{|r|}{ Indicators } & \multirow{2}{*}{$\begin{array}{l}\text { Strongly } \\
\text { Agree }\end{array}$} & \multirow[t]{2}{*}{ Agree } & \multirow{2}{*}{$\begin{array}{c}\text { Neither } \\
\text { Agree/Nor } \\
\text { Disagree }\end{array}$} & \multirow[t]{2}{*}{ Disagree } & \multirow{2}{*}{$\begin{array}{l}\text { Strongly } \\
\text { Disagree }\end{array}$} \\
\hline c1 & $\begin{array}{l}\text { Cultivate early-maturing rice varieties in dry and low precipitation } \\
\text { years }\end{array}$ & & & & & \\
\hline c2 & $\begin{array}{l}\text { Helping to farm water supply by dredging and restoration of } \\
\text { irrigation canals }\end{array}$ & & & & & \\
\hline c3 & $\begin{array}{l}\text { Prefer to plant of drought resistant rice varieties in drought } \\
\text { conditions }\end{array}$ & & & & & \\
\hline c4 & Do early planting in warmer weather & & & & & \\
\hline c5 & Tendency to agricultural insurance in climate changes conditions & & & & & \\
\hline c6 & Usage of plastic wrap on borders for prevention of farm water waste & & & & & \\
\hline c7 & Increase pesticide usage in dry and low rainfall years & & & & & \\
\hline c8 & Usage of intermittent irrigation in warm and dry conditions & & & & & \\
\hline c9 & Increase chemical fertilizer usage in dry and low precipitation years & & & & & \\
\hline $\mathrm{c} 10$ & Prefer to cultivation of high yielding varietiesin drought conditions & & & & & \\
\hline c11 & $\begin{array}{l}\text { Usage of wells and water pumps for irrigation in dry and low } \\
\text { precipitation years }\end{array}$ & & & & & \\
\hline c12 & Alternative crops cultivation instead of rice in drought conditions & & & & & \\
\hline c13 & $\begin{array}{l}\text { Receive Bank loans and governmental facilities in dry and low } \\
\text { precipitation years }\end{array}$ & & & & & \\
\hline c14 & Cultivate in less farm area in dry and low precipitation years & & & & & \\
\hline c15 & Prefer to stop cultivation in dry and low precipitation years & & & & & \\
\hline c16 & $\begin{array}{l}\text { Usage of wastewater (pond) building or irrigation in dry and low } \\
\text { precipitation conditions }\end{array}$ & & & & & \\
\hline c17 & Prefer to rent farm in dry and low precipitation years & & & & & \\
\hline c18 & Do direct rice cultivation in dry and low precipitation years & & & & & \\
\hline
\end{tabular}

\section{References}

1. Hosseini, S.; Mohammadi, F.; Mirdamadi, S.M.; Hosseini, S.M. The perception of greenhouse owners about environmental, economic and social aspects of sustainable agriculture in Iran. Int. J. Agric. Sci. Res. 2010, 1, 1-10.

2. Ghambarali, R.; Papzan, A.; Afsharzadeh, N. Analysis of farmers' perception of climate changes and adaptation strategies. J. Rural Res. 2012, 11, 192-213.

3. Zarafshani, K.; Sharafi, L.; Azadi, H.; Hosseininia, G.; De Maeyer, P.; Witlox, F. Drought vulnerability assessment: The case of wheat farmers in western Iran. Glob. Planet. Chang. 2012, 98, 122-130. [CrossRef]

4. Iglesias, A.; Garrote, L. Adaptation strategies for agricultural water management under climate change in Europe. Agric. Water Manag. 2015, 155, 113-124. [CrossRef]

5. Zarakani, F.; Kamali, G.; Chizari, A. The effect of climate change on the economy of rain fed wheat (a case study in Northern Khorasan). J.Agroecol. 2014, 6, 301-310. (In Persian)

6. Momeni, S.; Zibaie, M. Thepotential impacts of climate change on the agricultural sector of Fars Province. J. Agric. Econ. Dev. 2013, 27, 169-179. (In Persian)

7. Udmale, P.; Ichikawa, Y.; Manandhar, S.; Ishidaira, H.; Kiem, A.S. Farmers' perception of drought impacts, local adaptation and administrative mitigation measures in Maharashtra State, India. Int. J. Disaster Risk Reduct. 2014, 10, 250-269. [CrossRef]

8. Altschuler, B.; Brownlee, M. Perceptions of climate change on the Island of Providencia. Local Environ. 2016, 21, 615-635. [CrossRef]

9. Jin, J.; Gao, Y.; Wang, X.; Pham, K.N. Farmers' risk preferences and their climate change adaptation strategies in the Yongqiao District, China. Land Use Policy 2015, 47, 365-372.

10. Bojovic, D.; Bonzanigo, L.; Giupponi, C.; Maziotis, A. On-line participation in climate change adaptation: A case study of agricultural adaptation measures in Northern Italy. J. Environ. Manag. 2015, 157, 8-19. [CrossRef] [PubMed] 
11. Bryan, E.; Ringler, C.; Okoba, B.; CRoncoli, C.; Silvestri, S.; Herrero, M. Adapting agriculture to climate change in Kenya: Household strategies and determinants. J. Environ. Manag. 2013, 114, 26-35. [CrossRef] [PubMed]

12. Smith, P.; Olesen, J.E. Synergies between the mitigation of, and adaptation to, climate change in agriculture. J. Agric. Sci. 2010, 148, 543-552. [CrossRef]

13. Manandhar, S.; Pandey, V.P.; Kazama, F. Climate change and adaptation: An integrated framework linking social and physical aspects in poorly gauged regions. Clim. Chang. 2013, 120, 727-739. [CrossRef]

14. Deressa, T.T.; Hassan, R.M.; Ringler, C.; Alemu, T.; Yesuf, M. Determinants of farmers' choice of adaptation methods to climate change in the Nile Basin of Ethiopia. Glob. Environ. Chang. 2009, 19, 248-255. [CrossRef]

15. Gbetibouo, G.A. Understanding Farmers' Perceptions and Adaptations to Climate Change and Variability; International Food Policy Research Institute: Pretoria, South Africa, 2009.

16. Khoshnevisan, B.; Rajaeifar, M.A.; Clark, S.; Shamahirband, S.; Anuar, N.B.; Shuib, N.L.M.; Gani, A. Evaluation of traditional and consolidated rice farms in Guilan Province, Iran, using life cycle assessment and fuzzy modeling. Sci. Total Environ. 2014, 481, 242-251. [CrossRef] [PubMed]

17. Peykani, G.R.; Kelashemi, M.K.; Barikani, S.H.S.; Sasouli, M.R. Comparison of production productivity of 3 rice varieties including long grain good quality, Long Grain High Yielding and Hybrid Rice in Iran (Case Study: Gilan Province). J. Agric. Environ. Sci. 2008, 4, 625-632.

18. Pishgar-Komleh, S.H.; Sefeedpari, P.; Rafiee, S. Energy and economic analysis of rice production under different farm levels in Guilan province of Iran. Energy 2011, 36, 5824-5831. [CrossRef]

19. Oremo, F.O. Small-Scale Farmers' Perceptions and Adaptation Measures to Climate Change in Kitui County, Kenya. Ph.D. Dissertation, University of Nairobi, Nairobi, Kenya, 11 November 2013.

20. Motamed, M.K.; Devisti, H. Environmental and socio-economic impacts of Drought from the viewpoint of Guilan paddy farmers, North of Iran. Casp. J. Environ. Sci. 2012, 10, 227-235.

21. Abid, M.; Scheffran, J.; Schneider, U.A.; Ashfaq, M. Farmers' perceptions of and adaptation strategies to climate change and their determinants: The case of Punjab province, Pakistan. Earth Syst. Dyn. 2015, 6, 225-243. [CrossRef]

22. Yu, Q.Y.; Wu, W.B.; Liu, Z.H.; Verburg, P.H.; Xia, T.; Peng, Y.; Tang, H.J. Interpretation of climate change and agricultural adaptations by local household farmers: A case study at Bin County, Northeast China. J. Integr. Agric. 2014, 13, 1599-1608. [CrossRef]

23. Smith, W.J.; Liu, Z.; Safi, A.S.; Chief, K. Climate change perception, observation and policy support in rural Nevada: A comparative analysis of Native Americans, non-native ranchers and farmers and mainstream America. Environ. Sci. Policy 2014, 42, 101-122. [CrossRef]

24. Rogé, P.; Friedman, A.R.; Astier, M.; Altieri, M.A. Farmer strategies for dealing with climatic variability: A case study from the Mixteca Alta Region of Oaxaca, Mexico. Agroecol. Sustain. Food Syst. 2014, 38, 786-811. [CrossRef]

25. Arbuckle, J.G., Jr.; Morton, L.W.; Hobbs, J. Farmer beliefs and concerns about climate change and attitudes toward adaptation and mitigation: Evidence from Iowa. Clim. Chang. 2013, 118, 551-563. [CrossRef]

26. Amdu, B.; Ayehu, A.; Deressa, A. Farmers'Perception and Adaptive Capacity to Climate Change and Variability in the Upper Catchment of Blue Nile, Ethiopia; African Technology Policy Studies Network: Nairobi, Kenya, 2013.

27. Nizam, S. Farmers' perception on climate change. In Proceedings of the 3th International Symposium, Oluvil, Sri Lanka, 6-7 June 2013.

28. Nastis, S.A.; Michailidis, A.; Chatzitheodoridis, F. Climate change and agricultural productivity. Afr. J. Agric. Econ. 2012, 7, 4885-4893. [CrossRef]

29. Sofoluwe, N.A.; Tijani, A.A.; Baruwa, O.I. Farmers' perception and adaptation to climate change in Osun State, Nigeria. Afr. J. Agric. Res. 2011, 6, 4789-4794.

30. Tologbonse, E.B.; Auta, S.J.; Bidoli, T.D.; Jaliya, M.M.; Onu, R.O.; Issa, F.O. Farmers' perception of the effects of climate change and coping strategies in three agro-ecological zones of Nigeria. J. Agric. Ext. 2010, 14, 125-136. [CrossRef]

31. Hassan, R.; Nhemachena, C. Determinants of African farmers' strategies for adapting to climate change: Multinomial choice analysis. Afr. J. Agric. Resour. Econ. 2008, 2, 83-104.

32. Dezhkam, S.; Amiri, B.J.; Darvishsefat, A.A.; Sakieh, Y. Simulating the urban growth dimensions and scenario prediction through sleuth model: A case study of Rasht County, Guilan, Iran. GeoJournal 2014, 79, 591-604. [CrossRef] 
33. World Meteorological Organization. Analytical Tables. Available online: http://www.wmo.int/pages / index_en.html (accessed on 13 September 2016).

34. Travel Weather Average. Available online: http://weatherbase.com (accessed on 27 March 2016).

35. Kavian, A.; Dodangeh, S.; Abdollahi, Z. Annual suspended sediment concentration frequency analysis in Sefidroud basin, Iran. Model. Earth Syst. Environ. 2016, 2, 1-10. [CrossRef]

36. Woolson, R.F.; Bean, J.A.; Rojas, P.B. Sample size for case-control studies using Cochran's statistic. Biometrics 1986, 42, 927-932. [CrossRef] [PubMed]

37. Honts, C.R.; Alloway, W.R. Information does not affect the validity of a comparison question test. Leg. Criminol. Psychol. 2007, 12, 311-320. [CrossRef]

38. Krikeli, V.; Michailidis, A.; Klavdianou, N. Communication improvement through music: The case of children with developmental disabilities. Int. J. Spec. Educ. 2010, 25, 1-9.

39. Loizou, E.; Michailidis, A.; Chatzitheodoridis, F. Investigating the drivers that influence the adoption of differentiated food products: The case of a Greek urban area. Br. Food J. 2013, 115, 917-935. [CrossRef]

40. Le Dang, H.; Li, E.; Nuberg, I.; Bruwer, J. Understanding farmers' adaptation intention to climate change: A structural equation modelling study in the Mekong Delta, Vietnam. Environ. Sci. Policy 2014, 41, 11-22. [CrossRef]

41. Ogalleh, S.A.; Vogl, C.R.; Eitzinger, J.; Hauser, M. Local perceptions and responses to climate change and variability: The case of Laikipia district, Kenya. Sustainability 2012, 4, 3302-3325. [CrossRef]

42. Oluwatusin, F.M. The perception of and adaptation to climate change among cocoa farm households in Ondo State, Nigeria. Acad. J. Interdiscip. Stud. 2014, 3, 147-156. [CrossRef]

43. Shameem, M.I.M.; Momtaz, S.; Kiem, A.S. Local perceptions of and adaptation to climate variability and change: The case of shrimp farming communities in the coastal region of Bangladesh. Clim. Chang. 2015, 133, 253-266. [CrossRef]

44. Devkota, R.P. Climate change: Trends and people's perception in Nepal. J. Environ. Prot. 2014, 5, $255-265$. [CrossRef]

45. Falaki, A.A.; Akangbe, J.A.; Ayinde, O.E. Analysis of climate change and rural farmers' perception in North Central Nigeria. J. Hum. Ecol. 2013, 43, 133-140.

46. Fosu-Mensah, B.Y.; Vlek, P.L.; MacCarthy, D.S. Farmers' perception and adaptation to climate change: A case study of Sekyedumase district in Ghana. Environ. Dev. Sustain. 2012, 14, 495-505. [CrossRef]

47. Paudel, B.; Acharya, B.S.; Ghimire, R.; Dahal, K.R.; Bista, P. Adapting agriculture to climate change and variability in Chitwan: Long-term trends and farmers' perceptions. Agric. Res. 2014, 3, 165-174. [CrossRef] 